\title{
Becoming a hominid: Notes on the early taxonomy of Australopithecus
}

\author{
Goran Štrkalj \\ Department of Anatomical Sciences, University of the Witwatersrand, 7 York Rd., \\ Parktown 2193, South Africa, E-mail 055gor@chiron.wits.ac.za
}

\begin{abstract}
The paper attempts to trace the first suggestions that the Australopithecus should be classified as a hominid. It would appear that the first classification of Australopithecus as a member of the family Hominidae is to be found in the works of the German anthropologist Paul Adloff and the American scientist Dudley J. Morton. Adloff's and especially Morton's views, although largely neglected at the time when they were first articulated, represent the first steps towards the modern position on the taxonomy of Australopithecus.
\end{abstract}

KEY WORDS Taung, Australopithecus, Hominidae, Paul Adloff, Dudley J. Morton Prz. Antropol. - Anthropol. Rev. (2000), vol. 63, pp. 31-38, Fig. 1. ISBN 83-86969-60-1, ISSN 0033-2003

\section{Introduction}

Exactly seventy-five years ago, in February 1925, one of the most important discoveries in the history of paleoanthropology was announced to the scientific world and to the general public. It was the discovery of the Taung fossil, which consisted of an incomplete skull with a well-preserved mandible, and a natural endocranial cast of a juvenile individual. The fossil was found in a limestone mine near Taung, a village situated in what is now the Northwest Province of the Republic of South Africa. It was sent for scientific examination to Raymond A. Dart, Australian-born South African scientist, who was then the head of the
Department of Anatomy at the University of the Witwatersrand.

Dart interpreted the fossil as an ape with numerous 'humanoid' characters. He assumed it to be a 'missing link' - a being which belonged to the group which represented the evolutionary sequence between apes and humans - and created for it a new genus and species which he called Australopithecus africanus. This interpretation was, as is well known, rejected by the majority of the anthropological authorities of the day, most of whom saw in Australopithecus a new species of fossil ape, closely allied to African apes. Dart and a few partial or full early converts to his views such as $\mathrm{R}$. Broom, W. J. Sollas, W. K. Gregory and 


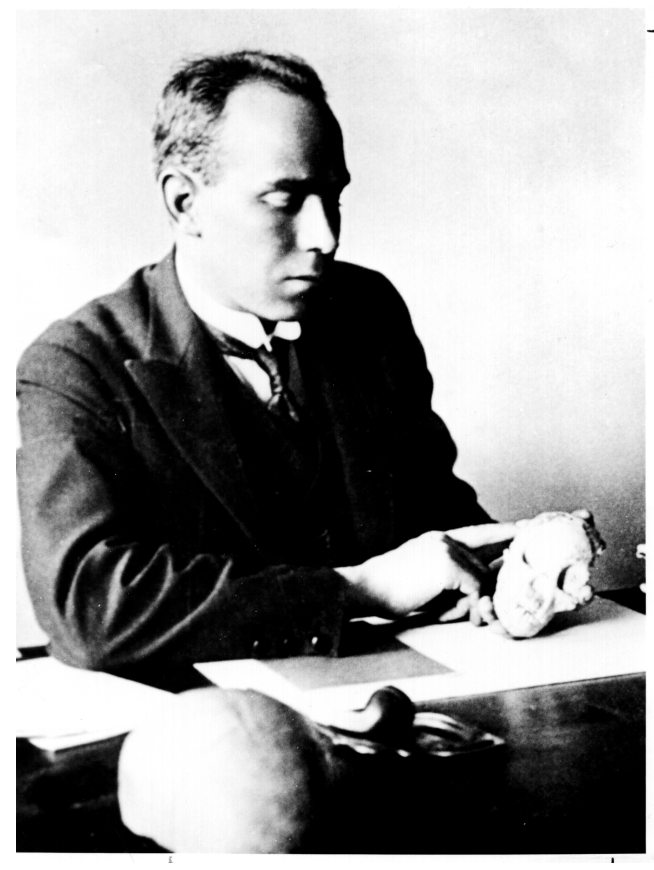

Fig. 1. Raymond Dart (1925) with the Taung skull

G. Elliot-Smith, thought of Australopithecus as a possible ancestor, or as a being closely allied to the modern ancestor of modern humans, but were not prepared (contrary to the position of contemporary paleoanthropology) to classify it in the family Hominidae. DART himself, created a new family for Australopithecus which he named in his first paper [1925] 'Homo-simiadae', or 'man-apes'. He, and most of those who accepted his ideas, usually referred to Australopithecus as a highly 'progressed' ape, a being 'on its way' to a fully human status. In this paper, an attempt will be made to trace the first suggestions that the Australopithecus should be classified as a hominid.

\section{P. Adloff and R. Broom}

In a detailed historical analysis of the Taung discovery TOBIAS [1984] empha- sised that Dart emphatically opposed the view that Australopithecus was a hominid species. He suggested that the first to classify the new species as such was Broom, who was to play a crucial role in the later acceptance of Dart's interpretation of australopithecines. According to Tobias, Broom did this in his 1933 classic The Coming of Man: Was it Accident or Design? TOBIAS [1998: p. 286] cites the following passage from BROOM'S book [1933: p. 143] as evidence: "Before Australopithecus was discovered some of us believed that the ancestor of man would be found in an anthropoid ape which had left the forest and taken to living on the plains and among the rocks; and here we have just such a form. Further, it shows a number of almost unexpected human characters. Personally, I believed that Australopithecus is very near to the human ancestor, and if not the member of the genus from which he sprang at least the member of the family. Certainly it is not at all nearly allied to chimpanzee."

However, it would appear that a different interpretation of this quotation is possible. It might be argued that Broom did not intend to say that Australopithecus belongs to the hominid family, but to the family form which the hominids evolved. This is in line with Dart's original view - that Australopithecus belongs to the family 'Homo-simiadae', which was ancestral to hominids. All of Broom's subsequent works could be cited in favor of this interpretation, because he does not refer to Australopithecus as a hominid in any of them [REED 1983]. In his last book Finding the Missing Link, he noted: "It seems a matter of little moment whether call the Australopithecids, apes, ape-man, or 
men" [BROOM 1950: p. 82]. As a consequence he was quite negligent as regards taxonomy and usually used, as did most of his contemporaries, elusive and imprecise vernaculars ('man-ape', 'ape-man', 'nearly man', etc.), which only made the existing taxonomic confusion and misunderstandings among anthropologists greater [LE GROS CLARK 1969; REED 1983].

BROOM [1950], as well as Dart [DART $\&$ CRAIG 1959], pointed at German anthropologist Paul Adloff as the one who went so far as to classify Australopithecus as a hominid in his 1932 paper. In this paper ADLOFF [1932] published the results of his study of the dentition of the Taung specimen. In 1929, Dart had managed to separate the lower and upper jaws of which casts were made, and distributed to dental experts, one of them being Königsberg Professor - P. Adloff. According to Adloff, the teeth of the Taung specimen were undoubtedly that of a hominid, and Australopithecus should, therefore, be classified as such. ADLOFF [1932: p. 154] concluded: "Das Gebiss von Australopithecus ist aber rein meschlich und lasst den Schluss zu, dass Australopithecus kein Anthropoide, sondern ein Hominide ist". Dart later commented on Adloff's conclusion in the following manner: "Professor T. (sic) Adloff in Germany was even more emphatic (than Gregory, see below). He stated that from his knowledge of the teeth of anthropoids he did not have the slightest hesitation in excluding Australopithecus form the anthropoids and claiming it is a genuine hominid (echte Hominide)" [DART \& CRAIG 1959: p. 54]. Other scientist did not agree with Adloff.

Austrian anthropologist - W. Abel, who studied the casts of Australopithecus at the same time, came to a completely different conclusion. In his monograph published in early 1930s, after a thorough study of the endocast, face and teeth, ABEL [1931] concluded that Australopithecus was an ape closely related to ancestral gorilla. W. K. Gregory, another prominent anthropologist and dental expert, was closer to Adloff in his findings. He concurred with Dart's original interpretation and emphasised: "if Australopithecus is not literally a missing link between the older dryopithecoid group and primitive man, what conceivable combination of ape and human characters would ever be admitted as such?" [GREGORY 1930: p. 650]. However, he was still not prepared to classify Australopithecus within the hominid family.

Three papers, published in 1939 by Gregory and his colleague from the American Museum - M. Hellman, are often referred to as the works in which they classified australopithecines in the hominid family (see, e.g., TATTERSALL [1995]). These papers [GREGORY \& HELLMAN 1939a,b,c] were written after their scientific excursion to South Africa, during which they examined the dental material of the australopithecines which had been recently discovered by Broom. And although the authors classified australopithecines in the subfamily Australopithecinae, they did not discuss whether these fossils belong to the family Hominidae. The fact that they were still not ready to accept their hominid status is suggested in the term 'man-ape' which they used in the titles of all three articles as a synonym for australopithecines.

It appears, therefore, that Adloff was alone in his conclusions. At that time, in early 1930s, they did not provoke any reaction. As REED [1983: p. 19] noted: 
"his (Adloff's) view was extreme for the time, and not even Dart and Broom or anyone else for several years showed such courage, but instead continued to regard Australopithecus as an 'advanced' ape."

\section{J. Morton}

It would appear, however, that the first suggestion, although only implicit, that Australopithecus should be classified among hominids is to be found even earlier, in the work of American scientist Dudley J. Morton. The fact that Morton was American is by no means fortuitous. Although some of the leading figures of American physical anthropology such as Hooton and Osborn dismissed Dart's claims, American anthropologists were generally more favorably orientated concerning Dart's interpretation of the Taung fossil than their European counterparts. As BOAZ [1981: p. 399] noted: "American anthropologists, perhaps because of their relatively sceptical view of Piltdown Man and the sequence of morphological changes it implied, were more receptive to Australopithecus than most European, particularly English and French, anthropologists." Morton was at that time (in 1927) affiliated to Yale University's Department of Surgery as well as to the American Museum of Natural History. He was interested in the evolution of upright posture and bipedal locomotion and had published several remarkable papers on this subject during the 1920s [MORTON 1922, 1924a,b, $1926 a, b, 1927]$. Bearing in mind the scarcity of fossils at the beginning of the century, and especially the small number of preserved bones relevant to the study of locomotion (which forced him to rely mainly on comparative anatomy of living primates), one can only admire the accuracy of Morton's inferences. Indeed, his insights were highly prized long after their initial publication (see, e.g., TOBIAS [1982]).

In one of the above mentioned papers, published only two years after the announcement of Dart's discovery, MORTON [1927] involved the Taung fossil in his discourse. Although Australopithecus is not directly mentioned in the text (as, indeed, some other important fossil hominids are not) it is present in the illustration which shows the primate phylogenetic tree. This phylogenetic tree had been adopted, with significant changes, from one of Gregory's (who was also working in the American Museum of the Natural History at that time) earlier papers [GREGORY 1916]. Just like Gregory, and contrary to the view of another great scientist from the American Museum - H. F. Osborn, Morton thought that great apes and humans are closely related, and that they both stem from the Dryopithecinae subfamily. From the Dryopithecinae group, argued Morton, evolved three lines of modern great apes (leading to modern gorillas, chimpanzees and orangutans). Within the human line MORTON [1927] listed the following fossils (from the oldest to the youngest): Taung, Pithecanthropus, Piltdown, Heidelberg, and Neanderthals (these are the names he used). It is obvious, therefore, that Morton, like Dart, and a few proponents of his thesis, assumed Australopithecus to be an ancestor or closely allied to the ancestor of modern humans. Morton's view on the exact taxonomic position of the Australopithecus, and all the others leading to modern humans, becomes obvious in the concluding 
chapters of the 1927 paper. To understand it, it is necessary to outline some of the basic propositions of Morton's understanding of human evolution.

Unlike many of his contemporaries Morton believed in mosaic evolution, that is, he maintained that some body parts became humanized earlier than others. Reluctance to accept mosaic evolution in the 1920s has been sometimes cited as one of the reasons for the initial rejection of Dart's claims on the nature of Taung fossil [TOBIAS 1982; WASHBURN 1985]. Furthermore, Morton, also in contradistinction to the many anthropological authorities of the era, argued that erect bipedalism had evolved first and that the system of locomotion had been the first to be transformed in human direction while other body parts, including the big brain, were to evolve later. The evolution of erect bipedalism, according to Morton, marked the appearance of hominid line. In contrast, other anthropologists who accepted that upright posture might have developed early in human evolution believed that it was a primitive trait which characterized common ancestor of apes and humans [BOWLER 1986]. It was generally believed that the big brain was a character which distinguished hominids from their ape relatives, that it had evolved early in human evolution and, accordingly, that any relatively small-brained creature, such as the Taung individual, could not be counted as hominid, no matter what other morphological features characterized it. Indeed, it would appear that the small brain was the main reason for Dart's decision not to include Australopithecus in the hominid family. Dart noted that it is evident "that a creature with anthropoid brain capacity, and lacking the distinctive, localized temporal expansion which appear to be concomitant with and necessary to articulate man, is no true man" [DART 1925: p. 198]. As TOBIAS [1998: p. 285] recently observed: "Although the child wore some of the clothing which was de rigeur among members of the hominid club, its hat-size was far too small for the child to be allowed into that august company." The fixation of anthropologists with the skull and brain and its importance in the study of human evolution have had a long history and can be traced back in preDarwinian era. STEPAN [1982] sees several different reasons for this, probably the most important being that the brain is 'the organ of mind', and mind was looked upon, from ancient times, as the differentia specifica which distinguishes humans from other living beings. Consequently, the size of the brain became the measure of humanity.

Returning to the problem of classification, the concluding chapters of MORTON's [1927] paper are of particular importance. Morton suggested that, in line with his views on human evolution, the definition of the genus Homo should be revised and made more inclusive. As bipedalism was the first human characteristic to develop (the one which signified a separation from the ape line), it appeared reasonable, to Morton, to include all bipedal species, within the line leading to modern humans, in the genus Homo. He noted in that respect: "According to the present interpretation, the grosser anatomical characteristics of mankind were acquired long before human psychological qualifications had been attained... It would seem that the generic term 'Homo' might be broadened to conform with a morphological classi- 
fication as to skeletal structure and stature. It could than include to a very considerable extent those countless generations of prehistoric human ancestry which, having acquired almost human proportions, were slowly and laboriously accumulating the mental equipment that was to be the greatest heritage of mankind" [MORTON 1927: p. 201]. Morton, therefore, went much further than anyone at that time. He not only included Australopithecus in the hominid family, but also implied that it should be classified as one of the Homo species. This thesis contradicted the prevailing view of the era, which was outlined above, and, as BOWLER [1986: p. 73] noted, "hardly anyone in the interwar years was prepared to accept Morton's position."

Today, however, Morton's views do not look that odd. Australopithecines have long been counted as members of the hominid family. They were even, when the Neo-Darwinian paradigm entered paleoanthropology, reclassified as Homo by MAYR [1950]. Although Mayr's suggestion was not accepted, it is interesting to note that nowadays some scientists are inclined to go even further than Morton and Mayr in making the taxon Homo more inclusive. Relying on data from the field of molecular biology which implies an extremely close relationship between apes and humans, they suggest that African apes - chimpanzee and gorilla - should be included in the genus Homo (see, e.g., WATSON et al. [1998]).

\section{Conclusions}

TOBIAS [1982: p. 7] once observed that "Dart's great contribution was that... he forced the world of palaeo- anthropology to appreciate that there had indeed been, at one time, small brained but upright walking members of the family of man... Dart's analysis of the Taung skull compelled scientists to another realization, namely that not all parts of the putative ancestor's bodies had become hominized or man-like at the same rate or time". Hence, the significance of D.J. Morton's work lies, among other things, in the fact that he arrived at the similar conclusions at the same time as Dart, if not before him. Morton's theoretical assumptions were to be corroborated by later fossil finds, and above all by subsequent discoveries of other australopithecine remains. The natural consequence of his views on human evolution was the inclusion of Australopithecus into human group.

In some recent works TOBIAS [1996, 1998] noted that Stent's concept of premature discovery can be a useful tool of historical analysis in paleoanthropology in general, and in the research on the Taung discovery in particular. STENT [1972: p. 84] defined premature discovery as one whose implications "cannot be connected by a series of simple logical steps to canonical, or generally accepted knowledge." Dart's discovery of Australopithecus africanus, argued Tobias, is a typical example of premature discovery, as Dart's interpretation was not compatible with the then prevailing theoretical framework. It should be noted, however, that there was a theoretical position within which Dart's claims were applicable: the one that was devised by Morton. Indeed, when some notable experts, such as Le Gros Clark, decided to accept Dart's views in the period after the Second World War they first had to change their understanding of human evolution 
along the lines developed by Morton [BOWLER 1986]. Morton's position, furthermore, has its relevance even in the context of modern paleoanthropology. However, his views on human evolution, phylogeny, and taxonomy have been neglected even more thoroughly than Dart's interpretation of the Taung fossil. Nevertheless, ideas such as Morton's and Adloff's, which from being the views of minority through the strange dialectics of scientific progress were to became that of majority, contributed towards the dissolution of the old view and the gradual acceptance of Australopithecus as a possible human ancestor, and eventually as a member of the hominid family, if not of the genus Homo.

\section{Acknowledgements}

I thank Professor Phillip V. Tobias for his encouragement and valuable comments. This research is funded by the University of the Witwatersrand's Postdoctoral Fellowship.

\section{References}

ABeL W., 1931, Kritische Untersuchungen über Australopithecus africanus Dart, Gegenbaurs morphologische Jahrbuch, 65, 539-640

Adloff P., 1932, Das Gebiss von Australopithecus africanus Dart: Einige erganzende Bemergungen zum Eckzahnproblem, Zeitschrift für Anatomie und Entwicklungsgeschichte, 97, 145-156

BoAz N. T., 1981, History of American paleoanthropological research on early Hominidae, 1925-1980, Am. J. Phys. Anthropol., 56, 397-406

Bowler P. J., 1986, Theories of Human Evolution: A Century of Debate, 1844-1944, John Hopkins University Press, Baltimore

Broom R., 1933, The Coming of Man: Was it Accident or Design?, Witherby, London

Broom R., 1950, Finding the missing link, Watts, London
DART R., 1925, Australopithecus africanus the man-ape of South Africa, Nature, 112, 195-199

DART R. A., D. CRAIG, 1959, Adventures with the Missing Link, Harper, New York

GREGORY W. K., 1916, Studies on the evolution of primates, Bulletin of the American Museum of Natural History, 35, 336-344

GREGORY W. K., 1930, The origin of man from a brachiating anthropoid stock, Science, 71, 645-650

Gregory W. K., M. Helman, 1939a, Fossil manapes of South Africa, Nature, 43, 25-26

Gregory W. K., M. Helman, 1939b, The dentition of the extinct South African man-ape Australopithecus (Plesianthropus) transvaalensis Broom. A comparative and phylogenetic study, Annals of the Transvaal Museum, 19, 339-373

Gregory W. K., M Helman, 1939c, The South African fossil man-apes and the origin of the human dentition, Journal of the American Dental Association, 26, 558-564

Le Gros Clark W. E., 1967, Man-apes or Apeman? The Story of Discoveries in Africa, Holt, Reinhart and Winston, Inc., New York

MAYR E., 1950, Taxonomic categories in fossil hominids, Cold Spring Harbor Symposia on Quantitative Biology, 15, 109-117

MORTON D. J., 1922, Evolution of the human foot. Part I, Am. J. Phys. Anthropol., 5, 305-336

MORTON D. J., 1924a, Evolution of the human foot. Part II, Am. J. Phys. Anthropol., 7, 1-52

MORTON D. J., 1924b, Evolution of the longitudinal arch of the human foot, Journal of Bone and Joint Surgery, 6, 17-24

MORTON D. J., 1926a, Significant characteristics of the Neanderthal foot, Nat. Hist., 26, 130134

MorTON D. J., 1926b, Evolution of man's erect posture, Journal of Morphology and Physiology, 43, 147-179

MorTON D. J., 1927, Human origin: correlation of previous studies of primate feet and posture with other morphological evidence, Am. J. Phys. Anthropol., 10, 173-203

REED C. A., 1983, A short history of the discovery and early study of the australopithecines: the first find to the death of Robert Broom (19251952), [in:] Hominid Origins: Inquiries Past and Present, Reichs, K. J. (ed.), University of America Press 
STEPAN N., 1982, The Idea of Race in Science: Great Britain 1800-1960, Archon Books, Hamden

Stent, G. S., 1972, Prematurity and uniqueness in scientific discovery, Sci. Am., 227, 84-93

Tattersall I., 1995, The Fossil Trail, Oxford University Press, New York and Oxford

Tobias P. V., 1982, Man the Tottering Biped: The Evolution of His Erect Posture, Committee in Postgraduate Medical Education, University of New South Wales, NSW Australia

Tobias P. V., 1984, Dart, Taung and the 'Missing Link', Witwatersrand University Press for the Institute for the Study of Man in Africa, Johannesburg
Tobias P. V., 1996, Premature discoveries in science with especial reference to Australopithecus and Homo habilis, Proc. Am. Phil. Soc., 14, 49-64

ToBias P. V., 1998, Ape-like Australopithecus after seventy years: was it a hominid?, J. Roy. Anthropol. Inst., (N.S.) 4, 283-308

Watson E., S. Esteal, D. Penny, 1998, Homo genus: a taxonomic revision, Paper presented at the Dual Congress, Sun City, South Africa, 28 June - 4 July 1998

WASHBURN L. S., 1985, Human Evolution after Raymond Dart, Witwatersrand University Press for the Institute for the Study of Man in Africa, Johannesburg

\section{Streszczenie}

Odkrycie przez Raymonda Darta czaszki z Taung (Australopithecus africanus), od którego ogłoszenia mija właśnie 75 lat, było jednym z najważniejszych wydarzeń w historii paleoantropologii. Było ono zarazem jednym z najbardziej kontrowersyjnych. Interpretacja Darta, że jest to czaszka małpy o wielu ludzkich cechach, która należała do wczesnego przodka (lub istoty blisko z tym przodkiem spokrewnionej) dzisiejszego człowieka, została ogólnie zaakceptowana dopiero ćwierć wieku później. Dart jednakże nie zdecydował się zaliczyć rodzaju Australopithecus do rodziny Hominidae. Utworzył dla niego nową rodzinę, którą w swej pierwszej publikacji [DART 1925] nazwał 'Homo-simiadae' lub „małpoludy”. Zarówno Dart, jak i wielu zwolenników jego poglądu, traktowali zazwyczaj australopiteka jak ,progresywną małpę”, znajdującą się „na drodze” do osiagnnięcia w pełni ludzkiego statusu.

Byli jednakże antropolodzy, którzy już wówczas, w niewiele lat po odkryciu, gotowi byli zaklasyfikować australopiteka do Hominidae. Jak się okazuje, pierwszym uczonym, który zasugerował taką klasyfikację był Amerykanin D.J. MORTON [1927]. Posunął się on nawet dalej, sugerując, że dziecko z Taung i oczywiście wszystkie dwunożne hominidy powinny być włączone do rodzaju Homo. Na początku lat trzydziestych, niemiecki antropolog P. ADLOFF [1932] zdecydowanie uznał australopiteki za przedstawicieli rodziny człowiekowatych. Rozstrzygającym kryterium dla uznania przez niego szczątków z Taung za przedstawiciela rodziny Hominidae miały ludzkie cechy uzębienia tej czaszki. Poglądy Mortona i Adloffa na ewolucję człowieka, które skłoniły ich do podjęcia takich decyzji różniły się od obowiązujących w tych czasach koncepcji i zostały zlekceważone, tymczasem pod wieloma względami są one antycypacją dzisiejszego punktu widzenia paleoantropologów na to zagadnienie. 